\title{
Evaluation of the effects of intra-row spacing on the growth and yield of maize (zea mays I.) in maize-ginger intercrop in samaru, northern guinea savanna of nigeria
}

\author{
LYOCKS, Sunday Wakili Jula; TANIMU, Joseph. ; DAUJI, La'ahki Zamani and \\ OGUNLEYE, Daniel Ayodeji.
}

\author{
Samaru College of Agriculture, Division of Agricultural Colleges \\ Ahmadu Bello University, Zaria. \\ Corresponding Author Lyocks, Sunday Wakili Jula.-email swjlyocks@yahoo.com \\ Phone: +2348023548026 OR +2347037695235
}

\begin{abstract}
The field experiment was conducted during the cropping seasons of 2009 and 2010 in Samaru, Zaria, Nigeria to evaluate the effects of various intra-row spaces on the growth and yield of maize intercropped into ginger. The experiment consisted of six treatments laid out in a Randomized Complete Block Design and replicated three times. The data collected were subjected to statistical Analysis of Variance and the treatment means were separated using the New Duncan Multiple Range Test at $\mathrm{P}<0.05$ level of significance. The results showed that the intercropped maize irrespective of spacing adopted, were consistently superior to the sole maize crop in dry matter production per plant, height per plant, number of leaves per plant and leave area per plant. The best grain yield of 3.78 tonnes/ha was obtained in maize spaced at $75 \times 75 \mathrm{~cm}$. The sole ginger crop gave rhizome yield (14.08 tonnes per hectare) was statistically higher than yields obtained in intercropped treatments. The intercropped treatments had yield advantages over the sole crop with maize Land Equivalent Ratio of $23-79 \%$. Therefore, maize at $75 \times 75 \mathrm{~cm}$ in ginger at $20 \times 20 \mathrm{~cm}$ was recommended as the best intercrop.
\end{abstract}

Key words: Maize, Ginger, Inter-Row, Intercropping, Nigeria.

\section{INTRODUCTION}

Intercropping is a popular farming system with small scale farmers in less developed, warm tropical regions such as Nigeria (Yunusa, 1985). The system is more common among near- subsistence, small scale farmers where traction force is largely human and animals and where temperature and moisture availability permits cultivation during most of the year. In areas with $400-700 \mathrm{~mm}$ of rainfall, simultaneous cropping tends to be practiced with crops of similar periods of maturity. In areas with $700-1000 \mathrm{~mm}$ of rainfall, the species in crop mixtures commonly have different periods of maturity, so that the later maturity crops can make maximum use of moisture at the end of the season. In areas with rainfall above $1000 \mathrm{~mm}$, simultaneous intercropping is practiced in combination with sequential multiple cropping. Low density intercropping is employed by many small scale farmers in areas subject to numerous biotic stresses to help ensure a dependable family food supply (Skinner, 1987).
The economic advantages of have been identified by Elemo et al, (1988) to include: high crop yield per unit area, more efficient use of environmental resources, labour saving, risk reduction in case where one of the crops in the mixture fails.

Nigeria is the largest ginger producer and exporter in Africa; and ranks fifth in the world (FAO, 2008). Most of Nigerian ginger production $(80 \%)$ comes from the southern part of Kaduna State and records show that the crop has been in production in that area since 1927 (Momber, 1942). Majority of the traditional ginger farmers in Nigeria cultivate sole ginger crop but under tree shades of locust bean tree (Musa, 1991). Studies have shown that ginger is a shade loving crop. However, with increases in ginger demand and land, population, urbanization, and changes in production pattern at present, cultivation of hectares ginger farm under wild tree shades is no longer plausible. Intercropping of ginger with some taller crops has been adopted in order to maintain the shade on the crop. Common among the crop mixtures are ginger intercropped with coconut, maize, 
cocoa oil palm, sugar cane, sorghum, okra, soybeans. According to Batugal et al., (1990), maize generally gives more shading to under storey crops like potato and ginger to reduce both air and soil temperature and thus favour tuber or rhizome production. In all intercrops, important considerations are given to inter and intra spacing of the crops involved with a view to deriving the full benefits of the crops combinations. Intercropping does not only increase diversity and resource efficiency in the agrosystem but also allows interaction between the individual crops involved in the combination. Van der Meer (1989) noted that both competition and facilitation take place in many intercropping systems, and that it is possible to obtain the net result of land equivalent ratio (LER where the complementary facilitation is contributing more to the interaction than the competitive interference. Thus, an LER $>1$ could result from low interspecific competition or strong facilitation. Yield advantages were determined using Land Equivalent Ratio (LER). LER provides that all other things being equal measure of the yield advantage obtained by growing two or more crops as an intercrop compared to growing the same crops as a collection of separate monoculture (Yancey, 1994). LER thus allows us to go beyond a description of the pattern of diversity into an analysis of the advantages of intercropping (Herrara and Harwood, 1974) information on ginger-maize intercropping are very scanty in literature.

This study was carried out to generate information on the appropriate ginger maize intercrop spacing that will give ginger farmers the best yield of ginger crop as a major crop without losing in the mixture as well as receiving the bonus of additional crop maize on the same field.

\section{MATERIALS AND METHODS}

This experiment was conducted during 2009 and 2010 cropping seasons on the research farm of Samaru College of Agriculture, Ahmadu Bello University, Zaria, located on latitude $11^{\circ} 11^{\prime} \mathrm{N}$ and longitude $07^{0} 38^{\prime}$ East in the northern guinea savanna ecological zone of Nigeria (Kowal and Kassam, 1973).

The intra-row spacing of early maturing maize (Zea mays L.) var. "SAMMAZ 17 white" was varied and intercropped in a Ginger (Zingiber officinale Roscoe) var. (UG 1 or Tafin Giwa as main crop). The experiment consisted of six treatments replicated three times. The treatments were: - Treatment 1, was sole ginger planted at $20 \times 20 \mathrm{~cm}$; Treatment 2, had maize planted at $75 \times 25 \mathrm{~cm}$; treatment 3 , maize at $75 \times 50 \mathrm{~cm}$; treatment 4 , maize at $75 \times 75 \mathrm{~cm}$; treatment 5, Maize at $75 \times 100 \mathrm{~cm}$. Treatments 2, 3, 4 , and 5 were intercropped in ginger at $20 \times 20 \mathrm{~cm}$ spacing, while treatment 6 was sole maize crop at 75 $x 25 \mathrm{~cm}$. A uniform cow dung application of $30 \mathrm{t} / \mathrm{ha}$ was applied to all plots.

Soil Analysis: The soil samples of the two locations were analysed by the following methods: The particle size distribution was determined by the standard hydrometer method (Klute, 1986). The soil pH was determined in water and $0.01 \mathrm{M} \mathrm{CaCl}_{2}$ with a $\mathrm{pH}$ glass electrode using soil: Solution ratio of 1:2.5. Organic carbon was determined by wet oxidation method of Walkley-Black (Nelson and Sommers, 1982). Exchangeable bases were determined by extraction with neutral $1 \mathrm{~N} \quad \mathrm{NH}_{4} \mathrm{OAC}$ saturation method. Potassium and $\mathrm{Na}$ in the extract were determined by flame photometer, while $\mathrm{Ca}$ and $\mathrm{Mg}$ were determined by atomic absorption spectrophotometer (Juo, 1979). Available $\mathrm{P}$ concentration in the extract was determined calorimetrically. Total $\mathrm{N}$ was determined by the Kjeldahl procedure (Bremner, 1982) (Table 1)

Table 1: Soil Chemical and Physical Characteristics of the Land Used For the Experiment in 2009 and 2010 Cropping Season at Samaru (0-30cmdepth)

\begin{tabular}{|c|c|c|}
\hline \multirow[b]{2}{*}{ Particle size distribution } & \multicolumn{2}{|c|}{ 0-30cm Depth } \\
\hline & 2009 & 2010 \\
\hline Sand $\left(\mathrm{g} \mathrm{kg}^{-1}\right)$ & 580 & 560 \\
\hline Silt $\left(\mathrm{gKg}^{-1}\right)$ & 300 & 310 \\
\hline Clay $\left(\mathrm{gKg}^{-1}\right)$ & 120 & 130 \\
\hline Soil Texture Class & $\begin{array}{l}\text { Sandy } \\
\text { Loam }\end{array}$ & $\begin{array}{l}\text { Sandy } \\
\text { Loam }\end{array}$ \\
\hline Chemical Properties & & \\
\hline $\mathrm{PH}$ in $\mathrm{H}_{2} \mathrm{O}(1: 2.5)$ & 5.90 & 5.80 \\
\hline $\mathrm{PH}$ in $0.01 \mathrm{M} \mathrm{Cacl}_{2}$ & 4.80 & 4.90 \\
\hline Organic Carbon $\left(\mathrm{g} \mathrm{kg}^{-1}\right)$ & 3.78 & 3.68 \\
\hline $\begin{array}{ll}\text { Available } & \text { Phosphorus } \\
\left(\mathrm{mg} \mathrm{kg}^{-1}\right) & \end{array}$ & 5.25 & 5.16 \\
\hline Total Nitrogen $\left(\mathrm{g} \mathrm{kg}^{-1}\right)$ & 3.50 & 3.48 \\
\hline C:N Ratio & 1.80 & 1.08 \\
\hline Calcium $\left(\mathrm{cmol} \mathrm{kg}^{-1}\right)$ & 4.40 & 4.38 \\
\hline Magnesium $\left(\mathrm{cmol} \mathrm{kg}^{-1}\right)$ & 0.84 & 0.82 \\
\hline Potassium $\left(\mathrm{cmol} \mathrm{kg}^{-1}\right)$ & 0.15 & 0.13 \\
\hline Sodium $\left(\mathrm{cmol} \mathrm{kg}^{-1}\right)$ & 0.40 & 0.40 \\
\hline
\end{tabular}


Cow dung Analysis: The cow dung samples were digested using wet oxidation method, Potassium and $\mathrm{Na}$ in digest was determined by flame photometer, while $\mathrm{Ca}$ and $\mathrm{Mg}$ were determined using atomic absorption spectrophotometer. Phosphorus content was determined by the vanadomolybdate yellow colour method (Juo, 1979); while N was determined by the micro-kjeldahl wet digestion method outlined by Bremner (1982). Organic Carbon was determined by the Walkley- Black method (Nelson and Sommers, 1982) (Table 2)

Table 2: Some Chemical Properties of the Cow Dung Manure used in the experiment at commencement of the study.

\begin{tabular}{|l|l|l|}
\hline \multirow{2}{*}{ Chemical Composition } & \multicolumn{2}{|c|}{ Amount in Manure } \\
\cline { 2 - 3 } & $\mathbf{2 0 0 9}$ & $\mathbf{2 0 1 0}$ \\
\hline Nitrogen $\left(\mathrm{g} \mathrm{kg}^{-1}\right)$ & 17.5 & 16.5 \\
\hline Phosphorus $\left(\mathrm{g} \mathrm{kg}^{-1}\right)$ & 4.5 & 4.7 \\
\hline Potassium $\left(\mathrm{g} \mathrm{kg}^{-1}\right)$ & 14.4 & 14.6 \\
\hline Calcium $\left(\mathrm{g} \mathrm{kg}^{-1}\right)$ & 28.6 & 27.5 \\
\hline Magnesium $\left(\mathrm{g} \mathrm{kg}^{-1}\right)$ & 4.2 & 4.2 \\
\hline Sodium $\left(\mathrm{g} \mathrm{kg}^{-1}\right)$ & 0.7 & 0.8 \\
\hline Organic Carbon $\left(\mathrm{g} \mathrm{kg}^{-1}\right)$ & 19.2 & 19.3 \\
\hline C:N Ratio & 1.10 & 1.17 \\
\hline
\end{tabular}

The field operations included one ploughing and two harrowing before the trial was laid out in beds (gross plot) measuring $9.0 \mathrm{~m}^{2}$ and net plots of $5.76 \mathrm{~m}^{2}$. The treatments were applied and the beds were immediately mulched using Isobelina doka_leaves after maize was planted.

Weeds were controlled using hand hoe and hand pulling at five and eight weeks after ginger planting.

Maize was manually harvested at sixteen weeks after planting, while ginger was harvested at twenty four weeks after planting.

The growth and performance parameter measured in maize were, the height per plant; number of leaves per plant; leaf area per plant; dry matter production per plant; and the yield parameters were, number of cobs per plot; cob yield per hectare; grain yield per plant, grain yield per hectare and 100 grain weight (g).

For the ginger crop, only the rhizome yield per hectare was determined. The data collected were subjected to analysis of variance (ANOVA) and significant treatment means were compared using the New Duncan Multiple Range Test (NDMRT) at 5\% level of probability. The Land Equivalent Ratio (LER) was used to determine intercropping advantages.

The LER was calculated using the formula LER $=\sum(Y p i / Y m i)$. Where $Y p$ is the yield of each crop in the intercrop or polyculture, and $\mathrm{Ym}$ is the yield of each crop in the sole crop or monoculture.

\section{RESULTS AND DISCUSSION}

The analysis of height per plant, dry matter production, number of leaves per plant and leaf area per plant for 2009 and 2010 combined were all significantly different among treatments. For all the growth parameters measured, treatments with maize planted at $75 \times 25 \mathrm{~cm}, 75 \times 50 \mathrm{~cm}$ and $75 \times 75 \mathrm{~cm}$ intercropped spacing, performed significantly better $(\mathrm{P}<0.05)$ than sole maize crop planted at $75 \times 25 \mathrm{~cm}$. The dry matter accumulation was highest(29.17 $\mathrm{g} /$ plant) for maize intercrop planted at $75 \times 25 \mathrm{~cm}$, which was significantly better than all other treatments with the least yield obtained in the sole maize crop treatment (Table 3 ). The numbers of leaves per plant and leaf area per plant were all statistically the same for all intercropped treatments but were significantly better than the sole maize crop. Plant heights in intercropped spacing wider than $75 \mathrm{X}$ $25 \mathrm{~cm}$ were significantly taller $(\mathrm{P}<0.05)$ than the sole maize plants treatment. The dry matter production was more efficient in the intercrops than sole cropping but treatment 1 dry matter was about $239 \%$ higher than other treatments'. This could be attributed to increased efficiency in environmental resource conservation and conversion into dry matter which the sole maize crops lacked. This result agrees with earlier findings of Willey (1979) and Shave et al., (2012) who reported that planting lower crops such as groundnuts, ginger and potatoes in intercrops usually serves as mulch or cover crops for taller crops such as pearl millet or maize. This type of combination reducing the rate of water loss and making more water available for use of the taller crop, in this case the maize crop. He further stated that the shorter or lower crops have mulching effects on the taller crop and aids erosion control, thereby conserving nutrients for use of the taller crop. The conserved moisture and nutrients remaining in situ without leaching or erosion force transporting away is an advantage for the intercropped treatments. Intercropping is also known to reduce weed density (Shave, et al., 2012). These enabled maize to absorb and grow continuously in a nutrient rich environment. This may therefore explain why maize performed better in all growth parameters when intercropped with ginger against the sole maize crop treatment. 
The advantages conferred on the intercropped maize treatments were also reflected in maize yield and yield parameters (Table 4). The Cob weight per plant was significantly higher $(P<0.05)$ in all treatments with wider intra-row spaces than closer spacing. As a result, maize planted at $75 \times 25 \mathrm{~cm}$ both in sole and intercropped treatments produced lighter cobs than other treatments with wider intercropped spacing. However, the weighed cobs per hectare were heavier in the closer spacing than the widest spacing of $75 \mathrm{X}$ $100 \mathrm{~cm}$. This means that the wider spacing provided enough space for plants to have higher nutrient uptake, because their roots could reach far and deep without much competition. The nutrients so absorbed were used and converted to yield heavy cobs. The weights of the cobs per hectare were compared among treatments, and it was found that maize planted at closer spacing appeared to have used the advantage of higher plants density to yield more cobs per hectare, which made up for the low cob sizes arising from closer spacing.

Table 3: Average Growth Parameters of Maize in 2009 and 2010 Growing seasons as affected by varying maize spacing in a maize/ginger inter crop in Samaru

\begin{tabular}{|c|c|c|c|c|}
\hline Treatments & $\begin{array}{c}\text { Dry } \\
\text { matter/plant (g) }\end{array}$ & $\begin{array}{l}\text { Height per } \\
\text { plant }(\mathrm{cm})\end{array}$ & $\begin{array}{c}\text { No. of } \\
\text { leaves/plant }\end{array}$ & Leaf Area/plant $\left(\mathrm{cm}^{2}\right)$ \\
\hline Ginger +Maize at $75 \times 25 \mathrm{~cm}$ & $29.17^{\mathrm{a}}$ & $119.90^{\mathrm{ab}}$ & $10.67^{\mathrm{a}}$ & $414.25^{\mathrm{a}}$ \\
\hline Ginger +Maize at $75 \times 50 \mathrm{~cm}$ & $13.83^{b}$ & $137.63^{\mathrm{a}}$ & $12.00^{\mathrm{a}}$ & $408.87^{\mathrm{a}}$ \\
\hline Ginger +Maize at $75 \times 75 \mathrm{~cm}$ & $13.00^{\mathrm{b}}$ & $158.80^{\mathrm{a}}$ & $12.33^{\mathrm{a}}$ & $559.24^{\mathrm{a}}$ \\
\hline $\begin{array}{l}\text { Ginger +Maize at } 75 \quad x \\
100 \mathrm{~cm}\end{array}$ & $12.17^{b}$ & $145.27^{\mathrm{a}}$ & $12.33^{\mathrm{a}}$ & $437.05^{\mathrm{a}}$ \\
\hline Sole Maize at $75 \times 25 \mathrm{~cm}$ & $10.00^{b}$ & $89.27^{\mathrm{D}}$ & $8.00^{b}$ & $221.90^{b}$ \\
\hline $\mathrm{SE} \pm$ & 5.434 & 11.462 & 0.703 & 31.975 \\
\hline
\end{tabular}

Means followed by unlike letters are significantly different at $5 \%$ level of probability using Duncan Multiple Range Test (DMRT)

Table 4: Average Yields and Yields Parameters of Maize and Yield of Ginger in 2009/2010 growing Seasons as Affected by Varying Spacing of Maize in a Maize/Ginger Intercrop in Samaru

\begin{tabular}{|c|c|c|c|c|c|c|c|}
\hline Treatments & $\begin{array}{c}\text { Cob } \\
\text { wt/pla } \\
\text { nt (kg) }\end{array}$ & $\begin{array}{c}\text { Cob } \\
\text { wt/ha } \\
\text { (tonne } \\
\text { s) }\end{array}$ & $\begin{array}{l}\text { Grain } \\
\text { yield } \\
\text { per } \\
\text { plant } \\
(\mathrm{kg})\end{array}$ & $\begin{array}{c}100 \\
\text { grain } \\
\text { weight } \\
(\mathrm{g})\end{array}$ & $\begin{array}{c}\text { Maize } \\
\text { grain } \\
\text { yield per } \\
\text { ha (tones) }\end{array}$ & $\begin{array}{c}\text { Fresh } \\
\text { ginger } \\
\text { rhizome } \\
\text { yield per ha } \\
\text { (tones) }\end{array}$ & $\begin{array}{c}\text { LER } \\
\text { (Maize) }\end{array}$ \\
\hline $\begin{array}{l}\text { Ginger }+ \text { Maize at } 75 \times \\
25 \mathrm{~cm}\end{array}$ & $0.08^{b}$ & $4.92^{a}$ & $0.06^{\mathrm{ab}}$ & 30.77 & $3.93^{\mathrm{ab}}$ & $7.82^{6}$ & 1.77 \\
\hline $\begin{array}{l}\text { Ginger }+ \text { Maize at } 75 \times \\
50 \mathrm{~cm}\end{array}$ & $0.10^{\mathrm{ab}}$ & $3.44^{\mathrm{ab}}$ & $0.08^{\mathrm{ab}}$ & 32.38 & $2.74^{\mathrm{abc}}$ & $8.94^{b}$ & 1.23 \\
\hline $\begin{array}{l}\text { Ginger }+ \text { Maize at } 75 \times \\
75 \mathrm{~cm}\end{array}$ & $0.20^{\mathrm{a}}$ & $4.81^{\mathrm{ab}}$ & $0.16^{\mathrm{a}}$ & 31.57 & $3.98^{\mathrm{a}}$ & $10.84^{\mathrm{ab}}$ & 1.79 \\
\hline $\begin{array}{l}\text { Ginger }+ \text { Maize at } 75 \times \\
100 \mathrm{~cm}\end{array}$ & $0.19^{\mathrm{a}}$ & $2.59^{b}$ & $0.15^{\mathrm{a}}$ & 29.66 & $2.05^{c}$ & $10.54^{\text {ab }}$ & 0.93 \\
\hline Sole Maize at $75 \times 25 \mathrm{~cm}$ & $0.04^{\mathrm{D}}$ & $2.72^{\mathrm{ab}}$ & $0.04^{\mathrm{b}}$ & 30.32 & $2.22^{\mathrm{bc}}$ & - & - \\
\hline Sole Ginger at $20 \times 20 \mathrm{~cm}$ & 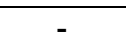 & - & - & - & - & $14.08^{\mathrm{a}}$ & 1 \\
\hline $\mathrm{SE} \pm$ & 4.124 & 0.034 & 0.034 & 2.002 & 0.582 & 1.560 & \\
\hline
\end{tabular}

Means followed by unlike letters are significantly different at $5 \%$ level of probability using Duncan Multiple Range Test (DMRT)

The results of maize grain yield per plant and per hectare showed that treatment 4 of $75 \times 75 \mathrm{~cm}$ maize spacing was the highest but not significantly higher than other intercropped treatments. The grain yields per plant and per hectare of the intercropped treatments were significantly higher than the sole 
maize treatment. These yields patterns collaborates Bruce et al., (2002) report that ear weights of maize declines with increasing plant density, but that the decline in kernel and ear weights did not adversely affect grain yield. Amede and Nigutu, (2001) however recommended that maize should be planted $25 \mathrm{~cm}$. In addition to the effects of spacing, the planting method might have contributed immensely to the low grain yield of sole maize. Abdullah et al., ((2008), and Bakht et. al., (2011) reported that maize yield was significantly $(\mathrm{P}<0.05)$ affected by planting methods. They reported that maximum grain yield of maize planted on ridges and were superior to raised beds methods, line sowing and broadcasted. The sole maize in this study was planted on raised beds which were liable to water logging and leaching thus depleting available nutrients needed for plant growth and development.

Fresh ginger rhizome yield was observed to be highest in the sole ginger treatment which produced rhizome that were significantly higher than those intercropped with maize. Rhizome yields declined with increasing maize density (as intra-raw spacing narrows) at $75 \times 50 \mathrm{~cm}$ and $75 \times 25 \mathrm{~cm}$. The sole ginger crop spacing was however statistically at par with treatments intercropped with maize at wider spacing of $75 \times 75 \mathrm{~cm}$ and $75 \times 100 \mathrm{~cm}$. This result suggests that over shading of the ginger crop by increased maize plant density was likely to have been responsible for the low rhizome yield occurred at closer maize ginger intercrop spacing.

The intercrop patterns were biologically more efficient than the sole crops. This was evidenced by the high Land Equivalent Ratios. The LER for all intercropping treatments except maize at $75 \times 100$ had an advantage ranging from $23-79 \%$ over the sole cropping thus indicating that most of the treatments had an advantage in land use (Table 4). This implies that $23-79$ percent more land would be required to produce the same amount of maize and ginger in sole culture. These findings were in agreement with reports by Pandey et al., (2006). However, it was noted that the high LER of maize might be due to the fact that the sole maize plot yields were far lower than the yield potentials of 5-6 tonnes per hectares. Nevertheless, treatment with maize planted at $75 \mathrm{X}$ 75 in ginger of $20 \times 20 \mathrm{~cm}$ gave the most beneficial yields in the intercrop.

\section{CONCLUSION}

The results of this study showed that ginger and maize could be intercropped. Intercropping is much more efficient in utilizing the available resources than sole cropping as indicated by the high LER values. Therefore, the appropriate maize/ginger intercrop in the Northern Guinea Savanna was found when ginger was planted at $20 \times 20 \mathrm{~cm}$ with maize intercropped at $75 \times 75 \mathrm{~cm}$. This combination gave the best yield of maize (3.98 tonnes per hectare), though far below potential yield of maize and highest LER of $79 \%$. The same intercrop also produced fresh ginger rhizome yields (10.84 tonnes per hectare) which were comparable to the yield of the sole ginger plots (14.08 tonnes per hectare).

\section{REFERENCES}

Amede, T. and Y. Nigutu (2001) Interaction of Components of Sweetpotato-Maize Intercropping Under the Semiarid Conditions of the Rift- Valley, Ethiopia. Tropical Agriculture, 78:1-7

Batugal, P.A., A. Dela Cruz, H.H. Libunao and A.A. Khweja, (1990). Intercropping potato with maize in lowland Philippines. Field Crops Res., 25:83-97

Bremner, J.M. (1982) Inorganic nitrogen. In: Page, A.L., Miller, R.H. and Reeney, D.S. (eds). Methods of Soil analysis. Part 2. Second Edition American Society of Agronomy, Madison, Wisconsin.

Bremner, J.S. and Mulvaney, C.S. (1982). Nitrogen total. In: Page, A.L., Miller, R.H. and Reeney, D.S. (eds). Methods of Soil analysis. Part 2. Second Edition American Society of Agronomy, Madison, Wisconsin. pp595-624.

Bruce WB, Edmeades GO Barker TC (2002). Molecular and physiological approaches to maize improvement for drought tolerance. Journal of Exp. Bot., 53: 13-25.

Elemo, K. A., Kumar, V., Olukosi, J. and Ogungile, A. (1988). Review of research on mixed cropping in the Nigeria Savannah, Samaru Miscellaneous paper. Institute for Agricultural Research, Zaria Nigeria.

FAO (2008) Food and Agriculture Organization of the United Nations: Economic and Social Development. The Statistical Data Division.

Herrara, W.A.T. and Harwood, R.R., (1974). The effects of plant density and row arrangement on productivity of com rice intercrop. Paper presented at the $5^{\text {th }}$ annual convention of the crop Science of Philippines, Nagar city, pp: 16-18.

Juo, A.R.S. (1979) Selection Method for soil and Plant analysis. IITA manual Series. No.1. Ibadan, Nigeria

Kowal, J.M. and Kassam, A.H. (1973). Productivity of crops in savannah and rainforest zones of Nigeria. Samaru Research Bulletin. 202:14. 
Klute, A. (1986). Methods of Soil Analysis No.9, Part 1 Second Edition, American Society of Agronomy, Madison, Wisconsin

Momber, E.W. (1942)" Southern Zaria Ginger Industry" Farm Forest (Nigeria Forester) 3:119-121

Musa, H.L. (1991). Ginger and Locust bean trees History, Growth, use and Potentials. Paper presented at TukHam symposium, Kurmin Musa, March, 29.

Nelson, D.W. and Sommers, L.E. (1982) Total Carbon, Organic Carbon and organic matter. In: A.L. Page, R.H. Miller and D.R. Keeney (eds). Methods of Soil Analysis No.9, Part 2, Chemical and Microbiological Properties American Society of Agronomy, Madison, Wisconsin. Pp 539-579.

Pandey, Y. R., Karki, T.B. And Paudel, G.P. (2006) Ginger integration in maize based cropping system for increased income in the hill of Nepal. Nepal journal of Science and Technology Vol. 7, P. 18-21.
Shave, P.A., A. Ter-Rumum and M.I. Enoch, (2012). Effects of of time of intercropping of mucuna (Mucuna cochinchinensis) in maize (Zea mays) for weed and soil fertility management. Int. J. Agric. Biol., 14: 469472

Skinner, P. (1987). The Tropical Agriculturist (maize) TCTA Macmillan. A Textbook. pp 62-69.

Van der Meer J (1989). The Ecology of Intercropping. Cambridge University Press, New York.

Yancey, Cecil Jr. (1994). Covers challenge cotton chemicals. The New Farm. February. Pp20-23.

Yunusa, I.A.M. (1985) Effects of plant population and arrangement on yield components of maize and soyabean mixture, Department of Agronomy, A.B.U. Zaria. Thesis (M Sc) 144p.

Wiley, R.W. (1979). Intercropping, its importance and research needs parts I and 2. Field Crop Absract. $32: 1-10$ and $73-85$ 